\title{
Efficacy of next-generation sequencing in bacterial zoonoses diagnostics
}

\author{
S. Duvnjak, Ž. Pavlinec, R. Vaser, K. Križanović, M. Šikić, M. Zdelar-Tuk, \\ I. Reil* and S. Špičić
}

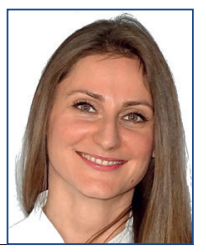

\section{Abstract}

Brucella, an extremely diverse but yet genetically highly homogenous genus of bacteria, has been a puzzle for scientists for many decades. These bacteria remain a prominent public health issue, particularly in the Balkan region. Correctly identifying and understanding the pathogen is a vital step in the epidemiology and epizootiology of any bacteria. Identification can be challenging, especially in the case of zoonotic species. This study aimed to implement fourthgeneration sequencing in the typing of 11 Brucella suis strains kept in our archive and to compare this method to the classical and nonsequencing based molecular methods used to date. Classical biotyping is highly subjective and gave inconclusive results for 3 strains. Molecular methods used were multiplex PCR and RFLP methods since no one method can identify both species and biovar which is vital in the case of Brucella suis infections. Species and biovars of all the strains were successfully confirmed and in concordance with biotyping results. Oxford Nanopore long-read sequencing was used on a MinION device for next-generation sequencing (NGS). Various algorithms were implemented for genome assembly and BioNumerics 8.0 software was used for MLST identification and analysis. MLST 21 was used for biovar identification and epidemiological comparison of tested strains. The assembled genomes were $3,2 \mathrm{Mb}$ in size and assembled into two chromosomes. MLST 21 analysis placed our strains into species and biovar clusters in concordance with other molecular tests used. To the extent of our knowledge, this is the first documented use of long-read sequencing in Brucella suis identification in this region. We conclude that bacteriological biotyping is outdated and hostspecific identification in this genus is incorrect and that molecular characterisation is always the safer, faster and more suitable option. MinION sequencing proved to be a strong, accessible solution for species determination. Future study is required to determine how detailed genome information it can give, considering the error rate.

Key words: Brucella suis; brucellosis; swine; horses; Nanopore MinION; NGS

Sanja DUVNJAK, BSc, PhD, Željko PAVLINEC, BSc, PhD, Croatian Veterinary Institute, Zagreb, Croatia; Robert VASER, BSc, PhD, Krešimir KRIŽANOVIĆ, BSc, PhD, Assistant Professor, Faculty of Electrical Engineering and Computing, Zagreb, Croatia; Mile ŠIKIĆ, BsC, PhD, Full Professor, Genome institute Singapore, A*STAR, 60 Biopolis St, Singapore; Maja ZDELAR-TUK, DVM, PhD, Irena REIL*, DVM, PhD, (Corresponding author, e-mail: reil@veinst.hr), Silvio ŠPIČIĆ, DVM, PhD, Croatian Veterinary Institute, Zagreb, Croatia 


\section{Introduction}

Brucellae belong to the $\alpha$-Proteobacteria, a class of bacteria that are extremely diverse and adaptable to new habitat conditions. Brucella sp. is a genus currently consisting of 13 species (Ledwaba et al., 2019), in contrast to the 6 species known in 2003 (Osterman and Moryion, 2003). Brucellae are known to infect wild and domestic animals such as wild boars, cows, sheep, goats, dogs (Godfroid, 2002), but have also recently been cultured from marine animals, common voles, red foxes, baboons, human breast implants and fish (Al Dahouk et al., 2007; Cvetnic et al., 2017; Scholz et al., 2008a, 2008b, 2010, 2016; Whatmore et al., 2014). Brucella suis was the first pathogen to be used as a bioweapon in the 1950s. This goes to show that this is a genus of highly adaptable bacteria that can realistically be expected anywhere. It is important to note that human neglect and misdiagnosis are two key factors that have facilitated these resourceful bacteria in remaining a globally persistent pathogen for well over a decade, causing significant economic losses and public health issues (Pappas et al., 2006).

Brucella suis causes the chronic disease known as porcine brucellosis, which manifests as infertility and miscarriage in sows, high mortality of piglets, and orchitis in boars. B. suis biovars 1, 2 and 3 appear around the world wherever pigs are bred, with biovars 1 and 3 the most abundant globally (OIE Manual, Porcine brucellosis, 2009).

Brucellosis is an endemic disease in Croatia, and various Brucella sp. have been confirmed in swine, wild boars, cows, sheep, goats and humans (Spicic et al., 2010). B. suis in Croatia is present in both domestic swine and wild boar populations in all counties where pigs are bred. Croatia was the first European country where $B$. suis biovar 3 infection was detected in horses, swine and wild boars. Swine in extensive production are most affected, given the high density of animals and proximity of wild boar that facilitate the spread of the disease (Cvetnic et al., 2003, 2005; Spicic et al., 2010). The prevalence of B. suis bv. 2 and the established link between wildlife and outdoor breeding has been reported in other European countries, such as Hungary, Poland, and others (Szulowski et al., 2013; Kreizinger et al., 2014). The most prevalent brucellosis in Croatia is swine brucellosis, though Croatia is one of few countries having a favourable brucellosis status. However, financially and professionally well-supported control and eradication programmes should be implemented to prevent this disease from becoming an even more serious problem than in the past. Unfortunately, this is not the case (Taleski et al., 2002; Pappas, 2010).

The omnipresence of brucellosis can only be combatted through accurate and detailed pathogen identification. Classical bacteriological methods are the gold standard for identification and classification. Since these methods are time-consuming, highly subjective and dangerous, molecular methods have been in use for over two decades. In the case of Brucellae, classical multiplex PCR and genotyping technics like MLVA and MLST are the most frequently used (Spicic et al., 2010; Duvnjak et al., 2015).

Brucella genomes are highly conserved and show a high degree of similarity with less than $6 \%$ nucleotide sequence variation, which is attributed to the recent origin of the genus (Bergey's Manual, 2018). They have two chromosomes and no plasmids. They have ribosomal gene clusters carrying around 3200 proteincoding genes according to SanchezJimenez et al. (2015). Also, Meyer and Shaw (Bergey's Manual, 2018) noted that Brucella suis bv. 3 is unique, with a single chromosome $3.2 \mathrm{Mbp}$ long. 
The global leader in next-generation sequencing technology is the Illumina platform (Illumina, Inc., San Diego, CA, USA), which uses synthesis-based sequencing (SBS) (www.illumina.com). The quality of its reads is still unmatching, library preparation takes hours and PCR is necessary, and the sequencing is not possible in the field. Further, the reads are usually small (max $300 \mathrm{bp}$ ) and the first results are expected after approximately 50-60 hours.

MinION ${ }^{\mathrm{TM}}$ (Oxford Nanopore Technologies (ONT), Oxford, UK) uses different technology based on $E$. coli nanopores. As the DNA molecule passes through the membrane it causes a change in membrane current, which is recorded and translated into base pairs. This enables the sequencing of very long individual DNA molecules and reading in real-time. The device itself is pocketsized and library preparation can take just 10 minutes, making it a powerful tool for on-site real-time sequencing. The error rate is higher than for Illumina, though it enables denovo assembly of whole and complex genomes because of the long stretches it produces (Goodwin et al., 2016). Its low price and constant improvements enable this device to become a better research tool that is being used to build and explore model (Tyson et al., 2017) and non-model organisms (Quick et al., 2017).

This study was aimed at introducing fourth-generation sequencing into our lab and for typing 11 Brucella suis strains to the biovar level. MinION is small, fast, simple and cost-effective since barcoding is possible. It takes less hands-on time during preparation than typing analyses currently in use if one has good software solutions. It also produces data that can be used for complete genome sequencing since it sequences long DNA molecules. However, the error rate is higher than Illumina sequencing. Therefore, the objective of this study was to determine its applicability for species and biovar typing of Brucellae.

\section{Materials and methods}

\section{B. suis strains}

The tested strains are listed in Table 1. All strains were also tested biochemically and using classical PCR-based molecular methods.

Table 1. Tested strains according to origin and year of isolation

\begin{tabular}{|l|l|l|}
\hline $\begin{array}{l}\text { SAMPLE } \\
\text { (CVI no.) }\end{array}$ & ORIGIN & YEAR \\
\hline 50 & swine & 2000 \\
\hline 58 & horse & 2003 \\
\hline 59 & horse & 2003 \\
\hline 60 & wild boar & 2003 \\
\hline 71 & referent B. suis bv. 3 & 2004 \\
\hline 72 & referent B. suis bv. 4 & 2004 \\
\hline 73 & referent B. suis bv. 5 & 2004 \\
\hline 76 & swine & 2004 \\
\hline 105 & swine & 2009 \\
\hline 196 & swine & 2015 \\
\hline 213 & referent B. suis bv. 2 & 2017 \\
\hline
\end{tabular}

\section{Methods}

All strains were microbiological, cultural and biochemically tested according to Corbel et al. (1983) and Alton et al. (1988). This involved colony morphology (size, convexity, transparency, roughness), $\mathrm{CO}_{2}$ growth requisite, susceptibility to thionine and fuchsine, production of $\mathrm{H}_{2} \mathrm{~S}$, agglutination with specific monosera, ability to hydrolyse urea and reaction with $\mathrm{Wb}, \mathrm{Iz}, \mathrm{Tb}$ and $\mathrm{R} / \mathrm{C}$ phages.

Bruce-ladder was used as the reference method to determine Brucella species (Lopez-Goni et al., 2008, 2011); and restriction fragment length 
polymorphism (RFLP) (Cloeckaert et al., 1995; Vizcaino et al., 1997) and multiplex-suis (Suis-ladder) were used to determine Brucella suis biovars (LopezGoni et al., 2011). MLVA-16 genotyping was performed on a total of 16 gene loci (Al Dahouk et al., 2005; Le Flèche et al., 2006). B. melitensis $16 \mathrm{M}$ was used as the reference strain for comparison and verification of test quality.

Strains were grown from cryobeads on Brucella agar plates for 72 hours at $37^{\circ} \mathrm{C}$. Bacterial cells were collected in nucleasefree water and resuspensions made with an absorbance of approximately 0.55 at $600 \mathrm{~nm}$ (Densimat, Biomerieux).

For PCR-based molecular methods, DNA was isolated using the QIAcube DNA Mini Kit and the QIAcube system (QIAGEN, Hilden, Germany) according to the manufacturer's instructions.

The supernatant $(2$ or $5 \mu \mathrm{L})$ was used in DNA-based tests. The same PCR reaction mixture was used for all molecular tests: $20 \mu \mathrm{L}$ reaction mixtures consisting of $10 \mu \mathrm{L}$ HotStarTaq Master Mix (Qiagen, Hilden, Germany), $6 \mu \mathrm{L}$ water (RNase-free water, Qiagen, Hilden, Germany), $0.5 \mu \mathrm{M}$ each primer pair specific for the target locus (Macrogen, Netherlands) and $2 \mu \mathrm{L}$ template DNA. The cycling regime differed from test to test but was done according to references. Amplifications were performed on the ProFlex thermocycler (Applied Biosystems, USA). For RFLP enzyme restriction, $20 \mu \mathrm{L}$ reaction mixture contained $5 \mu \mathrm{L}$ amplified DNA, $5 \mathrm{U}$ restriction enzyme, $2 \mu \mathrm{L}$ associated buffer (Fermentas, Burlington, Canada) and $12.5 \mu \mathrm{L}$ distilled water (DNase/ RNase Free Distilled Water, GIBCO, Invitrogen, Paisley, UK). Digestion was done at $37^{\circ} \mathrm{C}$ for 3 hours. Restriction products were analysed using capillary electrophoresis on the QIAxcel system (QIAGEN, Hilden, Germany) using High-Resolution DNA cartridge with size markers 100-2500 bp.
MLST and epidemiological analyses were performed using the BioNumerics software scheme (version 8.0; BioMerieux, Applied Maths, Belgium).

Genomic DNA isolation for sequencing started with centrifugation of the bacterial cell suspension at 5000 $\mathrm{g}$ for 10 minutes. The bacterial cell precipitate was treated according to the manufacturer's instructions using Genomic-tip 500/G (Qiagen). DNA quality and concentration were defined on DS-11 Spectrophotometer (DeNovix), Qubit using Qubit dsDNA BR Assay Kit (Invitrogen) and Tapestation 2200 using Genomic DNA Screen Tape and Reagents (Agilent). All samples were tested in triplicate on each device.

We prepared the sequencing library using the Rapid Barcoding Kit (ONT) with modifications to the RBK_9054 v2_revC_23Jan2018 protocol. We prepared a suspension of $9 \mu \mathrm{L}$ DNA $(\approx 1 \mu \mathrm{g}$ genomic DNA) and $3 \mu \mathrm{L}$ fragmentation mix and extended the incubation with AMPure XP beads to 10 minutes. Beads were washed with $80 \%$ ethanol and incubated for 30 seconds before removing the ethanol. After the second ethanol wash, beads were airdried for 1 minute and resuspended in $12 \mu \mathrm{L}$ Tris- $\mathrm{HCl} \mathrm{pH} 7.85$ without $\mathrm{NaCl}$ and incubated for 10 minutes. The remainder of the protocol was conducted on $10 \mu \mathrm{L}$ obtained DNA suspension. The samples were barcoded and sequenced.

Sequencing was performed on the MinION device using the FLO-MIN106 R9.4 flowcell. The sequencing run lasted 46 hours and produced 3.29 million reads with approximately 12.98 billion bases (for 12 samples).

\section{In-silico analysis}

Base-calling was done with Guppy version 3.6.0 using "dna_r9.4.1_450bps_ hac" as the configuration file and "SQKRBK004" as the barcoding kit. 


\begin{tabular}{|c|c|c|c|c|c|c|c|c|c|c|c|c|c|c|c|c|c|c|c|}
\hline $91 \mathrm{k}$ & dnak & gYrB & trpe & $\operatorname{cob} Q$ & 1nt_hyp & omp25 & prpe & CA $1 \mathrm{~A}$ & csdB & soxa & leux & $\operatorname{MN} 1 \mathrm{M}$ & fumc & fbaA & $\mathrm{dd} 1 \mathrm{~A}$ & puta & mutL & $\operatorname{acnA}$ & Key \\
\hline 4 & 29 & 4 & 3 & 5 & 1 & 2 & 5 & 2 & 4 & 2 & 2 & 1 & 1 & 4 & 2 & 3 & 2 & 1 & CVI_60 \\
\hline 7 & 35 & 3 & 3 & 5 & 3 & 2 & 5 & 2 & 8 & 3 & 2 & 1 & 24 & 4 & 1 & 3 & 2 & 6 & $\mathrm{CV}_{\text {_5 }} 50$ \\
\hline 4 & 1 & 3 & 3 & 5 & 1 & 2 & 5 & 2 & 4 & 2 & 2 & 27 & 1 & 4 & 2 & 3 & 2 & 1 & CVI_58 \\
\hline 4 & 1 & 4 & 3 & 5 & 1 & 2 & 5 & 2 & 4 & 2 & 2 & 1 & 1 & 4 & 2 & & 2 & 1 & CVI_59 \\
\hline 4 & 1 & 5 & 3 & 5 & 4 & 2 & 5 & 2 & 7 & 2 & 2 & 1 & 1 & 4 & 2 & 4 & 2 & 2 & CVI_71 \\
\hline 4 & 1 & 5 & 3 & 5 & 4 & 2 & 5 & 2 & 7 & 2 & 2 & 27 & 1 & 4 & 2 & 5 & 2 & 2 & CVI_72 \\
\hline 4 & 6 & 1 & 3 & 5 & 1 & 2 & 2 & 2 & 6 & 2 & 2 & 1 & 2 & 4 & 3 & 3 & 2 & 3 & $\mathrm{CVI}_{2} 73$ \\
\hline 4 & 1 & 3 & 3 & 5 & & 2 & 5 & 2 & 4 & 2 & 2 & & 4 & 4 & 1 & 3 & 2 & 1 & CVI_76 \\
\hline 4 & 1 & 3 & 3 & 5 & 1 & 2 & 5 & 2 & 4 & 2 & 2 & 1 & 1 & 4 & 1 & 3 & 2 & 1 & CVI_105 \\
\hline 7 & 35 & 3 & 3 & 5 & 3 & 2 & 5 & 2 & 8 & 3 & 2 & 1 & 24 & 4 & 1 & 3 & 2 & 6 & CVI_196 \\
\hline 7 & 1 & 3 & 3 & 5 & 3 & 2 & 5 & 2 & 8 & 3 & 2 & 4 & 3 & 4 & 1 & 3 & 2 & 3 & CVI_-213 \\
\hline
\end{tabular}

Figure 1. MLST 21 results

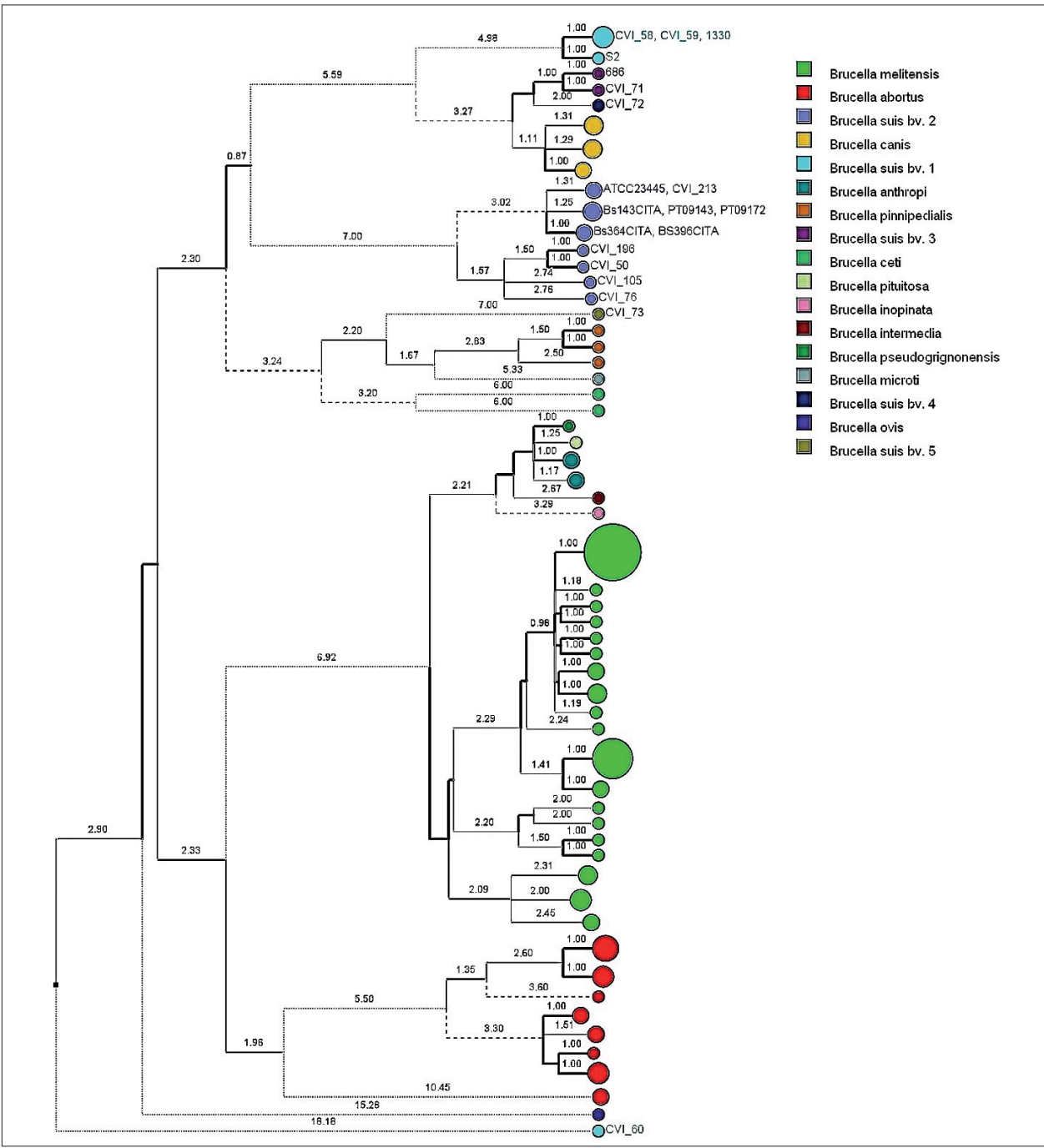

Figure 2. Dendrogram ladvanced clustering method, UPGMA network creation according to character data with permutation resampling 200) showing the tested Brucella suis strains compared to strains present in the PubMLST Brucella database (colour coding by species and biovar) 
For assembly, we used Raven version 1.1.5 (Vaser and Sikic, 2020), Wtdbg2 version 2.5 (Ruan and $\mathrm{Li}, 2019$ ) and Flye version 2.7.1 (Kolmogorov et al., 2019). Ten of the eleven barcodes were successfully assembled with Raven. A complete assembly for barcode 105 was possible only with Wtdbg2. Due to the lowest coverage, the assembly of barcode 7 is a combination of the Raven and Flye assemblies, as each of them completely assembled only one contig. All barcodes were later polished with Medaka version 1.0.1 (Medaka) using the model "r941_min_high_g360" and rotated with Circulator version 1.5.5 (Hunt et al., 2015). The evaluation was performed using BUSCO version 4.0.6 (Seppey et al., 2019), Quast version 5.0.2 (Gurevich et al., 2013) and Mauve version 2.4.0 (Darling et al., 2004).

\section{Results}

Biotyping identified the tested strains as follows: samples CVI_58, 59 and 60 inconclusive as Brucella suis biovar 1 or 3, samples CVI_50, 76, 105, 196 and 213 as biovar 2, sample CVI_71 as biovar 3; sample CVI_72 as biovar 4 and sample CVI_73 as biovar 5 .

Bruce-ladder identified all strains as Brucella suis. Since Bruce-ladder cannot be used to assign biovars, we used multiplex-suis and RFLP methods to identify the biovar. Both methods identified the strains in accordance with biotyping, except for strains 58, 59 and 60 that were identified solely as $B$. suis biovar 1 .

The MLST 21 results are presented in Figure 1 as calculated via BioNumerics using the PubMLST Brucella database.

The epidemiological analysis of the samples according to the MLST 21 results compared with international Brucella suis samples in the PubMLST Brucella database is presented in Figures 2, 3 and 4 as a dendrogram, planar network and minimum spanning tree.

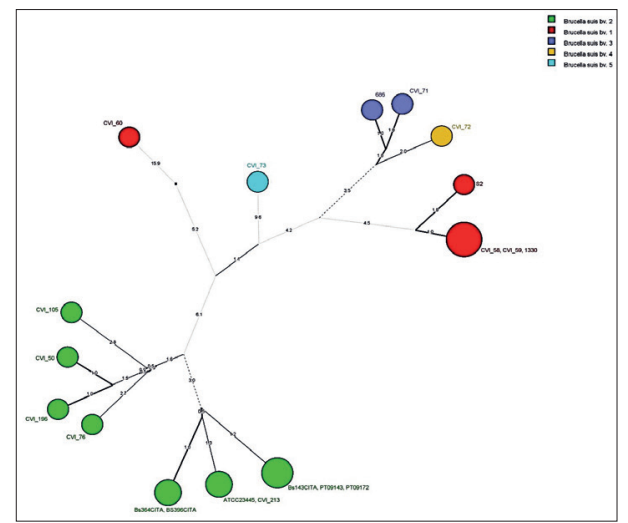

Figure 3. Planar network ladvanced clustering method, UPGMA network creation according to character data with permutation resampling 200) showing the tested Brucella suis strains compared to Brucella suis strains present in the PubMLST Brucella database /colour coding by biovar is presented on the right of the tree; strain names are presented next to the nodes; the number of locus variants is presented with the style of the line connecting samples - the thicker the line the fewer the number of locus variants)

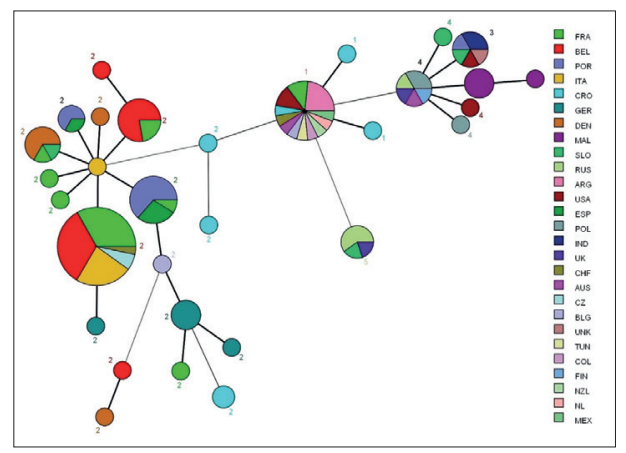

Figure 4. Minimum spanning tree (MST) showing the tested Brucella suis strains in relation to strains in the PubMLST Brucella database by country of origin and Brucella suis biovar (colour coding by country of origin is presented on the right of the tree; biovar characterisation is presented with numbers 1-5 next to the nodes; the number of locus variants is presented with the style of the line connecting samples - the thicker the line the fewer the number of locus variants)

DNA was isolated focusing on reads being as long as possible and DNA concentrations had to be just right to saturate enough pores but not to block 
them. After isolation, we used about 600 ng for barcoding and library preparation. We used approximately $1 \mu \mathrm{g}$ DNA for sequencing on the flowcell according to Tapestations calculations.

\section{In silico analysis}

In total, 1.69 million reads were successfully base-called across twelve barcodes. The statistics of each barcode are outlined in Table 2.

Bioinformation analyses resulted in complete, circular sequences of two chromosomes. The analysis revealed a BUSCO score of $>96 \%$ and QUAST average accuracy $>99.9 \%$. Chromosome sizes differ among biovars. GC\% was around $57.2 \%$. Genomes were deposited in NCBI under accession numbers CP054945 - CP054964.

\section{Discussion}

The virulence and epidemiology of Brucella sp. depend most on the species involved, particularly the species biovar. The results from this study show that biotyping is not the most suitable method for biovar assignation.
Bacterial genome sequencing has opened endless questions and possibilities. The key point in the sequencing itself is the correct isolation of DNA. The kit we used was a good choice. According to Tapestation 2200 (Agilent), DNA was of good concentration and length, enabling good sequencing output and resulting in good in silico analysis.

The genome structure of the strains tested here is consistent with previous findings: all strains from all biovars tested have two chromosomes, approximately 3.2 Mbp in size. GC content was, as expected, around $57.2 \%$ per chromosome. These findings are similar to those observed by other authors (Jumas-Bilak et al., 1998).

MLST 21 identified new MLST 21 genotypes not yet present in the database (CVI_50,60,71,72,73,105 and 196).Species identification, once compared with other isolates in the PubMLST database, gave the expected results. Strains clustered by biovar except for CVI_60 that clustered separately (Figures 2 and 3). Also, biovar 3 and 4 strains cluster closely together but can still be differentiated. Unlike MLVA typing (Duvnjak et al.,

Table 2. Read statistics of each barcode

\begin{tabular}{|c|c|c|c|c|c|}
\hline $\begin{array}{c}\text { Sample (CVI } \\
\text { no.) }\end{array}$ & $\begin{array}{c}\text { Number of } \\
\text { bases }\end{array}$ & $\begin{array}{c}\text { Number of } \\
\text { reads }\end{array}$ & Min length & $\begin{array}{c}\text { Average } \\
\text { length }\end{array}$ & Max length \\
\hline 50 & 526585080 & 117194 & 139 & 4493.28 & 142186 \\
\hline 58 & 524123652 & 145151 & 140 & 3610.89 & 158918 \\
\hline 59 & 461034491 & 91674 & 148 & 5029.06 & 141499 \\
\hline 60 & 500240474 & 164415 & 125 & 3042.55 & 133681 \\
\hline 71 & 520117515 & 190734 & 169 & 2726.93 & 136163 \\
\hline 72 & 521652873 & 173267 & 151 & 3010.69 & 179630 \\
\hline 73 & 353554241 & 44608 & 129 & 7925.80 & 148159 \\
\hline 76 & 307999956 & 126240 & 189 & 2439.80 & 43265 \\
\hline 105 & 517836990 & 216689 & 101 & 2389.77 & 38739 \\
\hline 196 & 526328311 & 120059 & 163 & 4383.91 & 112638 \\
\hline 213 & 522296048 & 165906 & 150 & 3148.14 & 65018 \\
\hline
\end{tabular}


2015), MLST 21 seems to be sensitive enough for biovar typing of Brucella suis strains. Separation of CVI_60 might be explained through Nanopore error rate though this assumption requires further investigation. Biovar 1 strains 58, 59 and 60 clustered with biovar 1 strains from the USA, Argentina, Mexico, Colombia, and Switzerland. Biovar 2 strains 50, 76, 105, 196 and 213 clustered with biovar 2 strains from Croatia and also with international strains, mostly from Europe. The referent strains of biovar 3, 4 and 5 (origin Slovenia) clustered with other strains of a certain biovar (Figure 4). It is also clear that the differences between biovars are minor, which might explain the reason why biovars are so difficult to identify, especially using nonmolecular methods.

Except for referent strains 71, 72, 73 and 213, all strains were regionally specific and unique in the diagnostic sense (Figures 3 and 4). There may be a possibility that this is connected to the unique virulent capabilities that allow them to circulate and survive more easily in this region, though this is merely an assumption. This study was aimed at more detailed identification of strains using new, recently available techniques.

MinION sequencing still has a higher error rate than Illumina, though researchers are improving this platform weekly. Combining Illumina and MinION reads is a perfect solution, rendering long stretches of DNA with MinION that are polished by very accurate Illumina sequences. However, Guppy version 3.6.0 greatly improved base-calling and the results were substantially better and comparable to the available Illumina sequences (Amaradinghe et al., 2020).

We conclude that MinION sequencing is a must-have in bacterial species identification. It is faster, highly specific and produces a huge amount of data that can be used for chromosomal investigation, antibiotic susceptibility, strain specificities and more, especially in combination with short-read sequencing like Illumina. Since this is the first documented use of long-read sequencing in Brucella suis identification in this region, the results are very promising, though a future detailed study is required.

Repositories: The assembled genomes have been deposited in NCBI under accession numbers CP054945 - CP054964.

\section{Acknowledgements}

This work was supported through the project "Brucella suis CRO TYPE - genome analysis" financed by Croatian Veterinary Institute's Fund for dedicated financing of scientific activities in 2018 (authors from CVI) and by the Croatian Science Foundation under the project "Single genome and metagenome assembly (IP-2018-01-5886)" (authors from FEEC). We are grateful for the excellent technical support of Marijana Novosel from the Croatian Veterinary Institute, Zagreb, Croatia.

\section{References}

1. AL DAHOUK, S., H. TOMASO, E. PRENGERBERNINGHOFF et al. (2005): Identification of Brucella species and biotypes using polymerase chain reaction-restriction fragment length polymorphism (PCR-RFLP). Crit. Rev. Microbiol. 31, 191-196.

2. AL DAHOUK, S., P. LE FLECHE, K. NÖCKLER et al. (2007): Evaluation of Brucella MLVA typing for human brucellosis. J. Microbiol. Meth. 69, 137-145.

3. ALTON, G. G., L. M. JONES, R. D. ANGUS and J. M. VERGER (1988): Techniques for the brucellosis laboratory. Paris: Institut National de la Recherche Agronomique.

4. AMARASINGHE, S. L., S. SU, X. DONG, L. ZAPPIA, M. E. RITCHIE and Q. GOUIL (2020): Opportunities and challenges in long-read sequencing data analysis. Genome. Biol. 21, 1-16. doi: 10.1186/s13059-020-1935-5

5. CLOECKAERT, A., J. M. VERGER, M. GRAYON et al. (1995): Restriction site polymorphism of the genes encoding the major $25 \mathrm{kDa}$ and $36 \mathrm{kDa}$ outer-membrane proteins of Brucella. Microbiol. 141, 2111-2121.

6. CORBEL, M. J., K. P. W. GILL and E. L. THOMAS (1983): Methods for the identification of Brucella. Weybridge, New Haw: Central Veterinary Laboratory, 1-63.

7. CVETNIC, Z., M. MITAK, M. OCEPEK et al. (2003): Wild boars (Sus scrofa) as reservoirs of Brucella suis biovar 2 in Croatia. Acta. Vet. Hung. 51, 465-473.

8. CVETNIC, Z., S. SPICIC, S. CURIC et al. (2005): Isolation of Brucella suis biovar 3 from horses in Croatia. Vet. Rec. 156, 584-585. 
9. CVETNIC, Z., S. DUVNJAK, M. ZDELAR-TUK et al. (2017): Swine brucellosis caused by Brucella suis biovar 2 in Croatia. Slov. Vet. Res. 54, 149-154.

10. DARLING, A. C. E., B. MAU, F. R. BLATTNER and N. T. PERNA (2004): Implicitfunction.Pdf. Genome. Res. 14, 1394-1403.

11. DUVNJAK, S., I. RACIC, S. SPICIC, M. ZDELARTUK and I. REIL (2015): Characterisation of Brucella suis Isolates from Southeast Europe by Multi-Locus Variable-Number Tandem Repeat Analysis. Vet. Microbiol. 180, 146-150.

12. GODFROID, J. (2002): Brucellosis in wildlife. Rev. Sci. Tech. 21, 277-286.

13. GOODWIN, S., J. D. MCPHERSON and W. R. MCCOMBIE (2016): Coming of age: Ten years of next-generation sequencing technologies. Nat. Rev. Genet. 17, 333-351.

14. GUREVICH, A., V. SAVELIEV, N. VYAHHI and G. TESLER (2013): QUAST: Quality assessment tool for genome assemblies. Bioinformatics 29, 1072-1075.

15. HUNT, M., N. D. E. SILVA, T. D. OTTO, J. PARKHILL, J. A. KEANE and S. R. HARRIS (2015): Circulator: Automated circularization of genome assemblies using long sequencing reads. Genome Biol. 16, 1-10.

16. ILLUMINA: https://www.illumina.com

17. JUMAS-BILAK, E., S. MICHAUX-CHARACHON, G. BOURG, D. O'CALLAGHAN and M. RAMUZ (1998): Differences in chromosome number and genome rearrangements in the genus Brucella. Mol. Microbiol. 27, 99-106.

18. KOLMOGOROV, M., J. YUAN, Y. LIN and P. A. PEVZNER (2019): Assembly of long, error-prone reads using repeat graphs. Nat. Biotechnol. 37, 540-546.

19. KREIZINGER, Z., J. T. FOSTER and Z. RÓNAI et al. (2014): Genetic relatedness of Brucella suis biovar 2 isolates from hares, wild boars and domestic pigs. Vet. Microbiol. 172, 492-498

20. LE FLÈCHE, P., I. JACQUES, M. GRAYON et al. (2006): Evaluation and selection of tandem repeat loci for a Brucella MLVA typing assay. BMC Microbiol. 6, 9-22.

21. LEDWABA, M. B., C. GOMO, K. E. LEKOTA et al. (2019): Molecular characterization of Brucella species from Zimbabwe. PLoS Negl. Trop. Dis. 13, e0007311. doi: 10.1371/journal.pntd.0007311

22. LOPEZ-GONI, I., D. GARCIA-YOLDI and C. M. MARIN et al. (2008): Evaluation of a multiplex PCR assay (Bruce-ladder) for molecular typing of all Brucella species, including the vaccine strains. J. Clin. Microbiol. 46, 3484-3487.

23. LÓPEZ-GOÑI, I., D. GARCÍA-YOLDI, C. M MARÍN, M. J. DE MIGUEL, E. BARQUEROCALVO, C. GUZMÁN-VERRI et al. (2011): New Bruce-ladder multiplex PCR assay for the biovar typing of Brucella suis and the discrimination of Brucella suis and Brucella canis. Vet. Microbiol. 154, 152-155.

24. MEDAKA: https://github.com/nanoporetech/ medaka
25. OIE Manual of Diagnostic Tests and Vaccines for Terrestrial Animals (2012): Chapter 2.8.5. Porcine brucellosis http://www.oie.int/fileadmin/Home/ eng/Health_standards/tahm/2.08.05_PORCINE_ BRUC.pdf (cited 26.4.2013.)

26. OSTERMAN, B. and I. MORIYON (2003): International committee on systematics of prokaryotes; subcommittee on the taxonomy of Brucella: minutes of the meeting, 17 September 2003, Pamplona, Spain. Int. J. Syst. Evol. Microbiol. 56, 1173-1175. Documentation of the Brucella nomenclature committee to return to species designations in an effort to document their usefulness in avoiding potential harm.

27. PAPPAS, G., P. PAPADIMITRIOU, N. AKRITIDIS et al. (2006): The new global map of human brucellosis. Lancet Infect. Dis. 6, 91-99.

28. PAPPAS, G. (2010): The changing Brucella ecology: novel reservoirs, new threats. Int. J. Antimicrob. Agents. 36 Suppl 1, S8-S11.

29. QUICK, J., N. D. GRUBAUGH, S. T. PULLAN, I. M. CLARO, A. D. SMITH, K. GANGAVARAPU et al. (2017): Multiplex PCR method for MinION and Illumina sequencing of Zika and other virus genomes directly from clinical samples. Nat. Protoc. 12, 1261-1266.

30. RUAN, J. and H. LI (2020): Fast and accurate long-read assembly with wtdbg2. Nat. Methods 17, 155-158.

31. SÁNCHEZ-JIMÉNEZ, M. M., J. P. ISAZA, J. F. ALZATE, M. OLIVERA-ANGEL (2015): Comparison of Brucella canis genomes isolated from different countries shows multiple variable regions. Genomics 106, 43-51.

32. SCHOLZ, H. C., Z. HUBALEK, J. NESVADBOVA et al. (2008a): Isolation of Brucella microti from soil. Emerg. Infect. Dis. 14, 1316-1317.

33. SCHOLZ, H. C., Z. HUBALEK, I. SEDLACEK et al. (2008b): Brucella microti sp nov., isolated from the common vole Microtus arvalis. Int. J. Syst. Evol. Microbiol. 58(Pt 2), 375-382.

34. SCHOLZ, H. C., K. NÖCKLER, C. GÖLLNER et al. (2010): Brucella inopinata sp. nov., isolated from a breast implant infection. Int. J. Syst. Evol. Microbiol. 60, 801-808.

35. SCHOLZ, H. C., S. REVILLA-FERNÁNDEZ, S. AL DAHOUK, et al. (2016): Brucella vulpis sp. nov., isolated from mandibular lymph nodes of red foxes (Vulpes vulpes). Int. J. Syst. Evol. Microbiol. 66, 20902098.

36. SEPPEY, M., M. MANNI and E. M. ZDOBNOV (2019): BUSCO: Assessing Genome Assembly and Annotation Completeness. In M. Kollmar (Ed.), Gene Prediction: Methods and Protocols (pp. 227-245). New York, NY: Springer New York doi: 10.1007/978-1-4939-9173-0_14

37. SPICIC, S., M. ZDELAR-TUK, I. RACIC, S. DUVNJAK and Z. CVETNIC (2010): Serological, bacteriological, and molecular diagnosis of brucellosis in domestic animals in Croatia. Croat. Med. J. 51, 320-326. 
38. SZULOWSKI, K., W. IWANIAK, M. WEINER and J. ZŁOTNICKA (2013): Brucella suis biovar 2 isolations from cattle in Poland. Ann. Agric. Environ. Med. 20, 672-675.

39. TALESKI, V., L. ZERVA, T. KANTARDJIEV et al. (2002): An overview of the epidemiology and epizootiology of brucellosis in selected countries of Central and Southeast Europe. Vet. Microbiol. 90, 147-155.

40. TYSON, J. R., N. J. O'NEIL, M. JAIN, H. E. OLSEN, P. HIETER, T. P. SNUTCH, M. G. ROSS, C. RUSS, M. COSTELLO, A. HOLLINGER, N. J. LENNON et al. (2017): Whole-genome sequencing and assembly of a Caenorhabditis elegans genome. Genome Biol. 14(5), doi: 10.1186/gb-2013-14-5-r51

41. VASER, R. and M. SIKIC (2020): Raven: a de novo genome assembler for long reads. bioRxiv 2020.08.07.242461 doi: 10.1101/2020.08.07.242461

42. VIZCAÍNO, N., J. M. VERGER, M. GRAYON et al. (1997): DNA polymorphism at the omp31 locus of Brucella spp:: evidence for a large deletion in Brucella abortus, and other species-specific markers. Microbiology 143, 2913-2921.

43. WHATMORE, A. M. (2014): Ancient-pathogen genomics: coming of age? mBio. 5(5), e01676-14 doi: 10.1128/mBio.01676-14

\section{Učinkovitost sljedeće generacije sekvenciranja u dijagnostici bakterijskih zoonoza}

Dr. sc. Sanja DUVNJAK, dipl. ing., dr. sc. Željko PAVLINEC, Hrvatski veterinarski institut, Zagreb, Hrvatska; dr. sc. Robert VASER, dipl. ing., dr. sc. Krešimir KRIŽANOVIĆ, dipl. ing., docent, Fakultet elektrotehnike i računarstva, Zagreb, Hrvatska; dr. sc. Mile ŠIKIĆ, dipl. ing. redoviti professor, Institut za genom Singapur, A*STAR, 60 Biopolis St, Singapur; dr. sc. Maja ZDELAR-TUK, dr. med. vet., dr. sc. Irena REIL, dr. med. vet., dr. sc. Silvio ŠPIČIĆ, Hrvatski veterinarski institut, Zagreb, Hrvatska

Rod Brucella biološki je iznimno raznolik, ali genetski vrlo homogen rod bakterija te je već desetljećima znanstvenicima nepoznanica. Ove bakterije su veliki javnozdravstveni problem, a osobito na Balkanu. Pravilno prepoznavanje i razumijevanje patogena ključan je korak u epidemiologiji i epizootiologiji bilo koje bakterijske vrste, čija identifikacija može biti izazovna, osobito u slučaju zoonotskih vrsta. Cilj je ovog rada bio implementirati sekvenciranje četvrte generacije u tipizaciji 11 sojeva Brucella suis koje se čuvaju u našoj arhivi te ovu metodu usporediti s klasičnim i molekularnim metodama koje se trenutačno primjenjuju, a ne zasnivaju se na sekvenciranju. Klasično je biotipiziranje vrlo subjektivno i dalo je podvojene rezultate za 3 soja. Od molekularnih metoda koristili smo višestruku lančanu reakciju polimerazom (engl. Polymerase Chain Reaction, PCR) i polimorfizam duljine restrikcijskih fragmenata (engl. Restriction Fragment Lenght Polymorphism, RFLP) budući da niti jedna od metoda ne može zasebno identificirati i vrstu i biovar, a što je važno u slučaju Brucella suis infekcije. Vrsta i biovar svih sojeva uspješno su potvrđene i u skladu s rezultatima biotipizacije. Sekvenciranje sljedeće generacije (engl. Next
Generation Sequencing, NGS) provodili smo na Oxford Nanopore MinION uređaju koji sekvencira duge lance DNK. Za sastavljanje genoma rabljeni su različiti algoritmi, a za identifikaciju i analizu rezultata MLST-a korišten je softver BioNumerics 8.0. MLST 21 je korišten za identifikaciju biovara i epidemiološku usporedbu ispitivanih sojeva. Genomi su bili veličine 3,2 Mb i sastavljeni u dva kromosoma. Analiza MLST 21 smjestila je naše sojeve $u$ vrsne i biovarne skupine $u$ skladu s drugim korištenim molekularnim testovima. Koliko je nama poznato, ovo je prva dokumentirana uporaba sekvenciranja dugih lanaca DNK u identifikaciji Brucella suis u jugoistočnoj Europi. Zaključujemo da je bakteriološka biotipizacija zastarjela i da je identifikacija biovara u ovom rodu, ovisno o domaćinu, netočna te da je molekularna karakterizacija uvijek sigurnija, brža i prikladnija opcija. MinION sekvenciranje pokazalo se kao vrlo pristupačno rješenje za određivanje vrste i biovara Brucella suis. Daljnja su istraživanja potrebna da bi se ustvrdilo koliko detaljne informacije o genomu može dati, imajući u vidu značajniji postotak pogreške prilikom sekvenciranja.

Ključne riječi: Brucella suis, bruceloza, svinje, konji, Nanopore MinION, sekvenciranje sljedeće generacije 